\title{
Novel Imidazole Substituted Bodipy-Based Organic Sensitizers in Dye-Sensitized Solar Cells
}

\author{
Mao Mao $\mathbb{D},{ }^{1}$ Xiao-Lin Zhang $\mathbb{D}^{1},{ }^{1}$ and Guo-Hua $W u^{2}$ \\ ${ }^{1}$ School of Atmospheric Physics, Nanjing University of Information Science \& Technology, Nanjing 210044, China \\ ${ }^{2}$ College of Science and Technology, Nihon University, 1-18-14 Kanda Surugadai, Chiyoda-ku, Tokyo 101-8308, Japan
}

Correspondence should be addressed to Mao Mao; mmao@nuist.edu.cn and Xiao-Lin Zhang; xlnzhang@nuist.edu.cn

Received 25 October 2017; Accepted 3 January 2018; Published 19 March 2018

Academic Editor: P. Davide Cozzoli

Copyright ( 2018 Mao Mao et al. This is an open access article distributed under the Creative Commons Attribution License, which permits unrestricted use, distribution, and reproduction in any medium, provided the original work is properly cited.

\begin{abstract}
A comparative study on the photophysical, electrochemical properties and photovoltaic performances of pure imidazole dyes containing varying linker groups is done. Two new organic dyes containing 4,5-bis(4-methoxyphenyl)-1H-imidazole (BPI) unit as an electron donor, boron dipyrromethene (Bodipy) chromophore as a conjugate bridge, cyanoacetic acid as an electron acceptor, and phenylene (BPI-P) or thienyl (BPI-T) as a additional linker have been synthesized for fabricating dye-sensitized solar cells (DSSCs). A reference dye (DPI-T) with 6,9-dimethoxy-1H-phenanthro[9,10-d]imidazole as the donor has also been synthesized for comparison. The overall conversion efficiencies of $0.18 \%, 0.32 \%$, and $1.28 \%$ were obtained for DSSCs based on BPI-P, BPI-T, and DPI-T, respectively. DPI-T was found to be more efficient than BPI-P and BPI-T because of its enhanced light harvesting efficiency and better coplanar geometry of the electronic structure.
\end{abstract}

\section{Introduction}

Global energy consumption and environmental pollution are leading to the increasing demand for viable renewable energy sources [1-4]. Dye-sensitized solar cells (DSSCs) are attractive solar energy conversion devices because of their peculiarity in terms of low-cost production, relative ease of fabrication, environmental friendliness, and stability, which paves the way to novel applications [5-9]. Besides the electrolyte and semiconductor, the performance of DSSCs is vitally influenced by the structural engineering of the sensitizing dyes, which absorb sunlight to generate electrons and transmit generated electrons [10-15]. Enormous studies have been focusing on searching novel fully organic dyes, providing advantages in terms of the molecularly tailored design flexibility and raw material abundance comparable to their inorganic counterparts. Most metal-free organic sensitizers with high efficiency contain dye molecules with linearly shaped structures comprising a strong $\mathrm{D}-\pi$-A dipole with an electron donor (D), a $\pi$-bridge, and an electron acceptor (A), which owns photoinduced intramolecular charge transfer natures $[16,17]$.
Imidazole, an archetypical heterocyclic molecule, is well known in the field of medicine as a drug with anticancer, antibacterial, and antifungal activities and as an antioxidant [18-21]. Recently, researchers have already introduced imidazole into organic light-emitting diode [22-26] and DSSC application [27-31] because of its attractive properties. According to previous studies, introducing electron donors in the 4,5-site and an electron acceptor in the 2-site of imidazole is propitious to form conjugated dipolar sensitizers as well as strengthen their light-harvesting capability. Moreover, as a result of weakening positive charge density at the donor group by electronic delocalization of the two substituents in the 4,5-site of the imidazolyl ring, charge recombination after electron injection may be retarded [27, 30]. Nevertheless, light sensitivity of imidazole photosensitizers in near-infrared spectra is limited. Boron dipyrromethene (Bodipy), known as the "little sister of porphyrins," is a unique chromophore with an intensive absorption profile in the visible/near-infrared region and could be conveniently and flexibly tuned by chemical modification at five different points of the Bodipy core [32]. Extensive efforts have been devoted to the development of Bodipy-modified dyes with a 


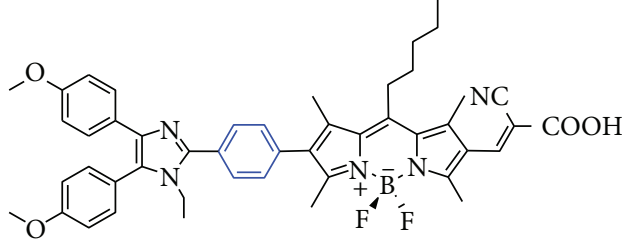

BPI-P

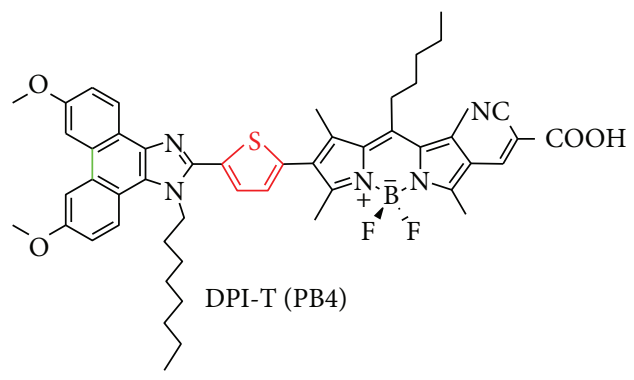

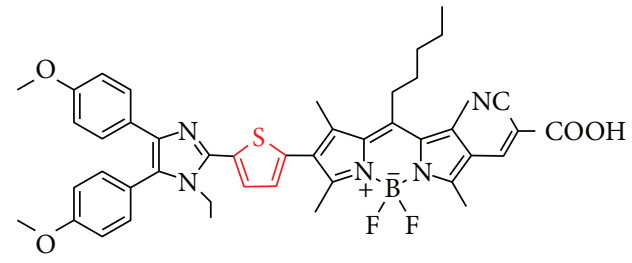

BPI-T

Figure 1: Molecular structures of the three dyes.

$\mathrm{D}-\pi$-A system to increase the light-harvesting properties [33-36]. With the aforementioned in mind, synthesis of some properties of new 4,5-di-substituted imidazole which is conjugated with Bodipy for broadening the spectral range could be worthwhile.

In the present work, two new organic sensitizers containing 4,5-bis(4-methoxyphenyl)- $1 H$-imidazole (BPI) and Bodipy as an electron donor and a conjugated bridge, respectively, along with different additional linker groups (phenylene for BPI-P and thienyl for BPI-T) incorporated into the bridge to further expand the absorption spectra and improve the solubility were synthesized and applied in DSSCs. 6,9-Dimethoxy-1H-phenanthro[9,10-d]imidazole (DPI) is structurally analogous to the BPI unit except for an additional single $\mathrm{C}-\mathrm{C}$ bond that links two phenyl rings. For the purpose of comparison, dye DPI-T [37] with DPI as the electron donor, Bodipy as the conjugated bridge, and thienyl unit as the additional linker was prepared. The corresponding molecular structures are shown in Figure 1. The structural and electronic properties of these sensitizers are also investigated using density functional theory (DFT) calculations.

\section{Experimental Section}

2.1. Materials. All reagents and materials in the experiments were purchased from Sigma-Aldrich and used without further purification. Solvents for measurements of spectroscopy are high-performance liquid chromatography (HPLC) grade. The starting materials (4-(1-ethyl-4,5-bis(4-methoxyphenyl)-1H-imidazol-2-yl)phenyl)boronic acid (3a), (5-(1ethyl-4,5-bis(4-methoxyphenyl)- $1 H$-imidazol-2-yl)thiophen -2-yl)boronic acid (3b), and DPI-T were prepared according to reported literatures $[27,37]$.

2.2. Characterization and Measurement. The NMR spectra were obtained using a Bruker AV spectrometer operating at $300 \mathrm{MHz}$ for ${ }^{1} \mathrm{H}$ NMR and $75 \mathrm{MHz}$ for ${ }^{13} \mathrm{C}$ NMR. MALDI-
TOF MS spectra were recorded on the Thermo LTQ Orbitrap mass spectrometer. UV-Vis absorption spectrum was performed on a Shimadzu UV/Vis-2450 spectrometer.

2.3. Synthesis and Characterization of New Compounds. The synthetic routes of BPI-P and BPI-T are depicted in Figure 2. We note that the synthesis routes of BPI-P and BPI-T are similar with the only difference in the linker unit. The synthetic routes start from a Suzuki coupling reaction of $3 \mathrm{a}$ and $3 \mathrm{~b}$ with 4 to afford the important precursor aldehyde intermediates $5 \mathrm{a}$ and $5 \mathrm{~b}$ in favorable yields, respectively. Afterwards, the target product dyes BPI-P and BPI-T were obtained through a Knoevenagel condensation reaction between 5 and cyanoacetic acid in the presence of piperidine. The structures of the two compounds were characterized using spectroscopy.

2.3.1. Synthesis and Characterization of $5 a$ and $5 b$. Under $\mathrm{N}_{2}$, compound $3(0.6 \mathrm{mmol})$ was reacted with $4(0.5 \mathrm{mmol})$ by Suzuki coupling reaction using $\mathrm{Pd}\left(\mathrm{PPh}_{3}\right)_{4}(50 \mathrm{mg})$ and $2 \mathrm{M}$ $\mathrm{K}_{2} \mathrm{CO}_{3}(3 \mathrm{~mL})$ aqueous solution as catalysis in the mixture solution of THF $(15 \mathrm{~mL})$ and toluene $(15 \mathrm{~mL})$ at $90^{\circ} \mathrm{C}$ for $12 \mathrm{~h}$. After cooling, water $(50 \mathrm{~mL})$ was added and the reaction mixture was extracted with $\mathrm{CH}_{2} \mathrm{Cl}_{2}(100 \mathrm{~mL})$. The combined organic layer was washed with brine, dried over anhydrous $\mathrm{MgSO}_{4}$, and evaporated under reduced pressure. The crude product was purified by column chromatography on silica gel using $\mathrm{CH}_{2} \mathrm{Cl}_{2}$ and EtOAc as eluent.

For 5a: red solid, yield: $80 \% . R_{\mathrm{f}}=0.15\left(\mathrm{CH}_{2} \mathrm{Cl}_{2} / \mathrm{EtOAc}\right.$ $100: 1)$. Mp $134-135^{\circ} \mathrm{C} .{ }^{1} \mathrm{H}$ NMR $\left(300 \mathrm{MHz}, \mathrm{CDCl}_{3}\right): \delta$ $10.14(\mathrm{~s}, 1 \mathrm{H}), 7.83(\mathrm{~d}, J=7.7 \mathrm{~Hz}, 2 \mathrm{H}), 7.50(\mathrm{~d}, J=8.0 \mathrm{~Hz}$, 2H), 7.36-7.34 (m, 4H), $7.03(\mathrm{~d}, J=8.5 \mathrm{~Hz}, 2 \mathrm{H}), 7.77$ (d, $J=8.6 \mathrm{~Hz}, 2 \mathrm{H}), 4.02-4.00(\mathrm{~m}, 2 \mathrm{H}), 3.90(\mathrm{~s}, 3 \mathrm{H}), 3.76(\mathrm{~s}$, $3 \mathrm{H}), 3.14(\mathrm{~m}, 2 \mathrm{H}), 2.81-2.78(\mathrm{~m}, 6 \mathrm{H}), 2.55(\mathrm{~s}, 3 \mathrm{H}), 2.42(\mathrm{~s}$, $3 \mathrm{H}), 1.69(\mathrm{~m}, 2 \mathrm{H}), 1.52-1.47(\mathrm{~m}, 2 \mathrm{H}), 1.44-1.37(\mathrm{~m}, 2 \mathrm{H})$, $1.10(\mathrm{t}, J=7.1 \mathrm{~Hz}, 3 \mathrm{H}), 0.94(\mathrm{t}, J=7.1 \mathrm{~Hz}, 3 \mathrm{H}) .{ }^{13} \mathrm{C} \mathrm{NMR}$ $\left(75 \mathrm{MH}_{\mathrm{Z}}, \mathrm{CDCl}_{3}\right): \delta 186.1,159.9,158.5,158.2,155.8,149.4$, $146.3,140.2,139.9,137.9,136.0,134.0,133.1,132.4,131.2$, 

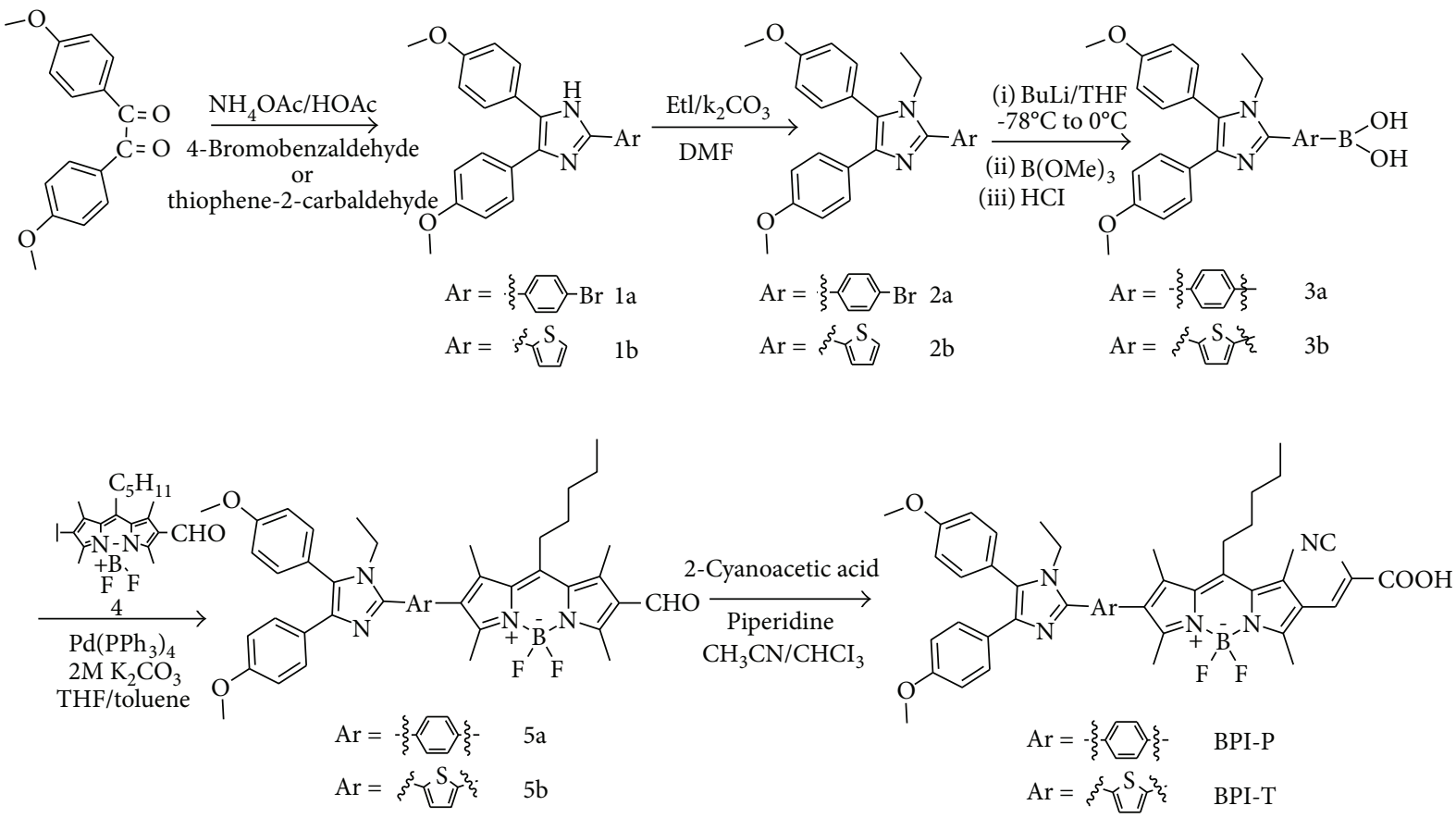

FIgUre 2: Synthetic route to the dyes BPI-P and BPI-T.

$130.5,130.4,129.3,129.1,128.7,128.6,128.4,127.8,127.5$, $126.1,123.6,114.6,113.5,55.3,55.2,39.6,32.5,31.6,28.9$, $22.5,16.4,14.9,14.0,13.8,13.0,12.7$. IR $\left(\mathrm{KBr}, \mathrm{cm}^{-1}\right): 1667$ (s), 1539 (s), 1495 (s), 1323 (m), 1247 (m), 1177 (m), 1073 (m), 1024 (m). MALDI-TOF MS calcd for $\left([\mathrm{M}+\mathrm{H}]^{+}\right)$ $\mathrm{C}_{44} \mathrm{H}_{48} \mathrm{BF}_{2} \mathrm{~N}_{4} \mathrm{O}_{3}$ : 729.3782, found: 729.3780 .

For 5b: dark solid, yield: $89 \% . R_{\mathrm{f}}=0.25\left(\mathrm{CH}_{2} \mathrm{Cl}_{2} / \mathrm{EtOAc}\right.$ $100: 1)$. Mp $183-185^{\circ} \mathrm{C}$. ${ }^{1} \mathrm{H}$ NMR $\left(300 \mathrm{MHz}, \mathrm{CDCl}_{3}\right): \delta$ $10.15(\mathrm{~s}, 1 \mathrm{H}), 7.48-7.46(\mathrm{~m}, 3 \mathrm{H}), 7.32(\mathrm{~d}, J=8.4 \mathrm{~Hz}, 2 \mathrm{H})$, $7.03(\mathrm{~d}, J=8.4 \mathrm{~Hz}, 2 \mathrm{H}), 6.98(\mathrm{~m}, 1 \mathrm{H}), 6.77(\mathrm{~d}, J=8.4 \mathrm{~Hz}$, $2 \mathrm{H}), 4.08-4.06(\mathrm{~m}, 2 \mathrm{H}), 3.90(\mathrm{~s}, 3 \mathrm{H}), 3.77(\mathrm{~s}, 3 \mathrm{H}), 3.15(\mathrm{~m}$, $2 \mathrm{H}), 2.82-2.79(\mathrm{~m}, 6 \mathrm{H}), 2.56(\mathrm{~s}, 3 \mathrm{H}) ; 2.52$ (s, 3H), 1.46-1.41 $(\mathrm{m}, 6 \mathrm{H}), 0.96(\mathrm{t}, J=6.9 \mathrm{~Hz}, 3 \mathrm{H}), 0.88-0.86(\mathrm{t}, J=7.1 \mathrm{~Hz}, 3 \mathrm{H})$. ${ }^{13} \mathrm{C} \mathrm{NMR}\left(75 \mathrm{MH}_{\mathrm{Z}}, \mathrm{CDCl}_{3}\right): \delta 186.1,160.0,158.6,158.3$, $156.3,149.9,141.5,140.7,140.1,138.1,134.9,134.2,133.7$, $132.4,130.6,129.1,128.4,127.9,127.4,127.2,126.5,126.3$, $125.9,123.1,114.6,113.6,55.3,55.1,39.6,32.5,31.6,28.9$, $22.5,16.3,15.1,14.8,13.9,13.1,12.8 . \mathrm{IR}\left(\mathrm{KBr}, \mathrm{cm}^{-1}\right): 1681$ (m), 1538 (s), 1505 (s), 1323 (m), 1248 (m), 1175 (m), 1063 (m). MALDI-TOF MS calcd for $\left([\mathrm{M}+\mathrm{H}]^{+}\right) \mathrm{C}_{42} \mathrm{H}_{46} \mathrm{BF}_{2} \mathrm{~N}_{4} \mathrm{O}_{3} \mathrm{~S}$ : 735.3346, found: 735.3343 .

2.3.2. Synthesis and Characterization of BPI-P and BPI-T. Compound $5(0.20 \mathrm{mmol})$ and 2-cyanoacetic acid $(0.60 \mathrm{mmol})$ were mixed with $20 \mathrm{~mL} \mathrm{MeCN}$ and $20 \mathrm{~mL}$ $\mathrm{CHCl}_{3}$. The mixture was heated to reflux for $24 \mathrm{~h}$ in the presence of a few drops of piperidine. After cooling to room temperature, solvents were removed by rotary evaporation. The residue was extracted with $\mathrm{CH}_{2} \mathrm{Cl}_{2}$, washed with brine, and dried over anhydrous $\mathrm{Na}_{2} \mathrm{SO}_{4}$. The solvent was evaporated under reduced pressure, and the crude product was purified by column chromatography on silica gel with $\mathrm{CH}_{2} \mathrm{Cl}_{2}$ and $\mathrm{MeOH}$ as eluent to afford target dyes.
For BPI-P: red solid, yield: $87 \% . R_{\mathrm{f}}=0.45\left(\mathrm{CH}_{2} \mathrm{Cl}_{2} /\right.$ $\left.\mathrm{CH}_{3} \mathrm{OH} 3: 1\right)$. Mp 192-193 ${ }^{\circ} \mathrm{C} .{ }^{1} \mathrm{H} \mathrm{NMR}\left(300 \mathrm{MHz}, \mathrm{CDCl}_{3}\right)$ : $\delta 8.09(\mathrm{~s}, 1 \mathrm{H}), 7.86(\mathrm{~m}, 2 \mathrm{H}), 7.51(\mathrm{~d}, J=8.5 \mathrm{~Hz}, 2 \mathrm{H}), 7.34-$ $7.26(\mathrm{~m}, 4 \mathrm{H}), 7.02(\mathrm{~m}, 2 \mathrm{H}), 6.80(\mathrm{~d}, J=7.5 \mathrm{~Hz}, 2 \mathrm{H}), 4.03$ $(\mathrm{m}, 2 \mathrm{H}), 3.88(\mathrm{~s}, 3 \mathrm{H}), 3.77(\mathrm{~s}, 3 \mathrm{H}), 2.98(\mathrm{~m}, 2 \mathrm{H}), 2.48$ (s, 6H), $2.34(\mathrm{~s}, 6 \mathrm{H}), 1.48-1.36(\mathrm{~m}, 6 \mathrm{H}), 1.10(\mathrm{t}, J=7.1 \mathrm{~Hz}$, $3 \mathrm{H}), 0.89(\mathrm{~m}, J=6.9 \mathrm{~Hz}, 3 \mathrm{H})$. IR $\left(\mathrm{KBr}, \mathrm{cm}^{-1}\right): 1724(\mathrm{~m})$, 1614 (m), 1538 (s), 1390 (m), 1248 (m), 1015 (s). MALDITOF MS calcd for $\left([\mathrm{M}+\mathrm{H}]^{+}\right) \mathrm{C}_{47} \mathrm{H}_{49} \mathrm{BF}_{2} \mathrm{~N}_{5} \mathrm{O}_{4}$ : 796.3846, found: 796.3840 .

For BPI-T: dark solid, yield: 87\%. $R_{\mathrm{f}}=0.50\left(\mathrm{CH}_{2} \mathrm{Cl}_{2} /\right.$ $\left.\mathrm{CH}_{3} \mathrm{OH} 3: 1\right)$. Mp 203-205 ${ }^{\circ} \mathrm{C} .{ }^{1} \mathrm{H}$ NMR $\left(300 \mathrm{MHz}, \mathrm{CDCl}_{3}\right.$ ): $\delta 8.12(\mathrm{~s}, 1 \mathrm{H}), 7.72(\mathrm{~m}, 1 \mathrm{H}), 7.49(\mathrm{~d}, J=7.5 \mathrm{~Hz}, 2 \mathrm{H}), 7.34$ $(\mathrm{d}, J=7.5 \mathrm{~Hz}, 2 \mathrm{H}), \quad 7.05-7.03(\mathrm{~m}, 3 \mathrm{H}), 6.82-6.80 \quad(\mathrm{~d}$, $J=7.5 \mathrm{~Hz}, 2 \mathrm{H}), 4.13(\mathrm{~m}, 2 \mathrm{H}), 3.89$ (s, 3H), 3.77 (s, 3H), 3.01 (m, 2H), 2.59-2.55 (m, 6H), 2.46 (s, 3H), 2.38 (s, 3H), 1.64 (m, 2H), 1.48-1.40 (m, 4H), $1.27(\mathrm{t}, J=7.1 \mathrm{~Hz}, 3 \mathrm{H}), 0.93(\mathrm{t}$, $J=7.1 \mathrm{~Hz}, 3 \mathrm{H})$. IR $\left(\mathrm{KBr}, \mathrm{cm}^{-1}\right): 1715(\mathrm{~m}), 1612(\mathrm{~m}), 1537$ (s), 1249 (m), 1202 (s), 1012 (s). MALDI-TOF MS calcd for $\left([\mathrm{M}+\mathrm{H}]^{+}\right) \mathrm{C}_{45} \mathrm{H}_{47} \mathrm{BF}_{2} \mathrm{~N}_{5} \mathrm{O}_{4} \mathrm{~S}: 802.3404$, found: 802.3404 .

2.4. Fabrication and Characterization of the DSSC Devices. The nanocrystalline titanium dioxide $\left(\mathrm{TiO}_{2}\right)$ electrode and the platinum $(\mathrm{Pt})$ cathode were prepared according to our previous report [37]. Nanocrystalline electrodes are about $14.5 \mu \mathrm{m}$ thick [determined by a profilometer (XP-2, AMBIOS Technology Inc.)]. The $\mathrm{TiO}_{2}$ electrodes were immersed in a dry $\mathrm{CHCl}_{3}$ solution containing $0.3 \mathrm{mM}$ dye sensitizer for $12 \mathrm{~h}$ at the room temperature to ensure complete dye uptake and were then rinsed with anhydrous $\mathrm{CHCl}_{3}$ and $\mathrm{EtOH}$ to remove the unbound dye. The dye-coated $\mathrm{TiO}_{2}$ films were placed under vacuum for further drying and used as the photo-anode in the DSSCs. A thermally Pt counter 


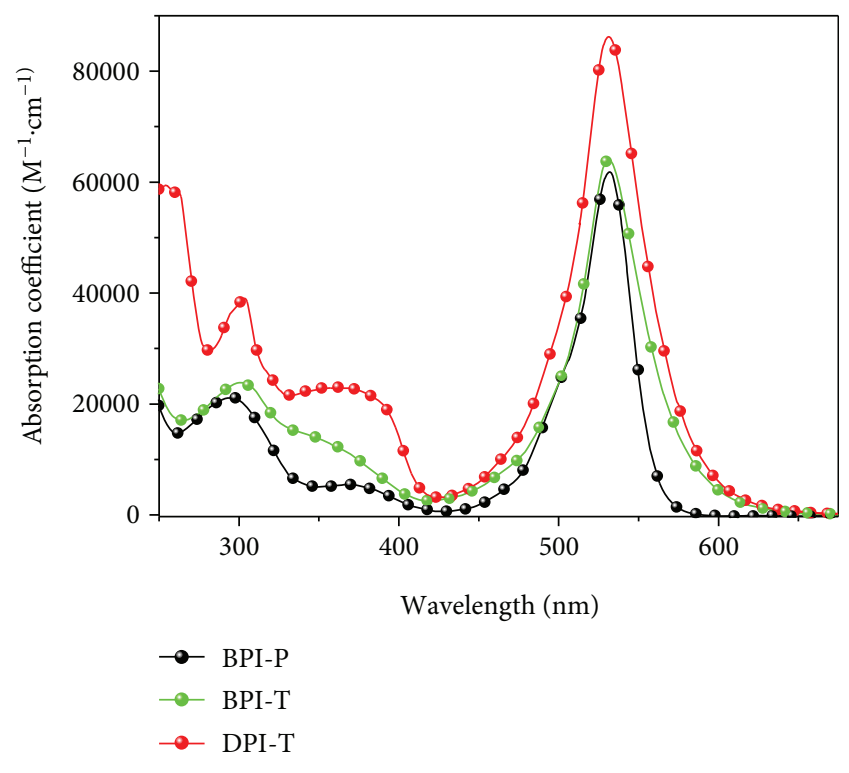

FIGURE 3: Absorption spectra of the dyes BPI-P, BPI-T, and DPI-T in $\mathrm{CHCl}_{3}$ (conc. $\left.=1.0 \times 10^{-5} \mathrm{M}\right)$.

electrode was then combined with the dye-adsorbed $\mathrm{TiO}_{2}$ electrode by use of a hot-melt Surlyn film as a spacer to produce a sandwich-type electrochemical cell, and then an electrolyte was injected into the seam between two electrodes. An acetonitrile $\left(\mathrm{CH}_{3} \mathrm{CN}\right)$ solution containing 1,2-dimethyl-3- $n$-propylimidazolium iodide $(0.6 \mathrm{M})$, LiI $(0.1 \mathrm{M}), \mathrm{I}_{2}(0.05 \mathrm{M})$, and tert-butylpyridine (TBP, $\left.0.5 \mathrm{M}\right)$ was used as an electrolyte. The opening was sealed with Araldite glue after filling the electrolyte. To prevent inflated photocurrents arising from stray light, a black metal mask surrounding the active area was a testing cell during all measurements. The active geometrical area of the DSSCs was $0.25 \mathrm{~cm}^{2}(0.5 \mathrm{~cm} \times 0.5 \mathrm{~cm})$. The cell parameters were obtained under incident light with an intensity of $100 \mathrm{~mW} \cdot \mathrm{cm}^{-2}$ using a Keithley 2420 3A source meter controlled by Test-point software under a solar simulator (solar AAA simulator, oriel USA, calibrated with a standard crystalline silicon solar).

\section{Results and Discussion}

3.1. Photophysical Properties. The UV-Vis absorption spectra of BPI-P, BPI-T, and DPI-T in $\mathrm{CHCl}_{3}$ solution are depicted in Figure 3, and the characteristic parameters are listed in Table 1. The absorption spectra of all sensitizers show two distinct bands in the range of $250-675 \mathrm{~nm}$. The shorter wavelength region (250-400 nm) is assigned to the aromatic $\pi-\pi^{*}$ electron transition of BPI or DPI with an additional linker, whereas the longer wavelength region with high-intensity absorption (420-650 nm) corresponds to the Bodipy unit with some intramolecular charge transfer transition. The $\lambda_{\max }$ (absorption maximum wavelength) of BPI-P with molar absorption coefficient $(\varepsilon)$ of $62,000 \mathrm{M}^{-1} \cdot \mathrm{cm}^{-1}$ and BPI-T with $\varepsilon$ of $64,000 \mathrm{M}^{1} \cdot \mathrm{cm}^{-1}$ are both at about $531 \mathrm{~nm}$, due to the similar chemical structures except for the additional linker substituents. Remarkably, resulting from its increased donor property and smaller steric hindrance between the thiophene and BPI unit (vide infra), the thienyl-containing dye (BPI-T) shows an apparent broadening especially for longer wavelength when compared to the phenylene-containing dye (BPI-P). Generally, the better conjugation in the thiophenebased analogue would cause some small bathochromic shift of the band maximum, not only its broadening. The $\mathrm{CHCl}_{3}$ solution is medium-polarity solvent, and aggregation of the studied dyes is very probable in it. To verify this, their absorption spectra have been measured in some highpolarity solvent, such as $\mathrm{CH}_{3} \mathrm{CN}$ solution. However, the UV/Vis absorption spectra of BPI-P and BPI-T in $\mathrm{CH}_{3} \mathrm{CN}$ which exhibit simultaneously blue shifts of ca. $11 \mathrm{~nm}$ compared to those in the medium-polarity solvent.

Additionally, the reference dye DPI-T has a relatively red-shifted absorption maximum wavelength and greater molar absorption coefficient than BPI-T. This is presumably caused by two reasons: on the one hand, the torsion angle between the DPI and thiophene is smaller than BPI and thiophene (vide infra), leading to favorable charge transfer from the donor unit to the acceptor unit; on the other hand, the electron-donating ability of DPI is stronger than that of BPI due to the fact that four aromatic rings in the former are more propitious to conjugate extension. Based on the above analysis, the order of the light-harvesting ability is DPIT > BPI-T > BPI-P.

Upon adsorption onto the nanocrystalline $\mathrm{TiO}_{2}$ films (Figure 4), the $\lambda_{\max }$ values for BPI-P, BPI-T, and DPI-T are $505 \mathrm{~nm}, 527 \mathrm{~nm}$, and $528 \mathrm{~nm}$, respectively. The absorption spectra of all three sensitizers on the $\mathrm{TiO}_{2}$ films exhibited significantly hypsochromic shift and a broader full width at half maximum (fwhm) than absorption spectra measured in $\mathrm{CHCl}_{3}$ due to strong interactions between the dyes and $\mathrm{TiO}_{2}$ surfaces. Meanwhile, both in solutions and on $\mathrm{TiO}_{2}$ film, the fwhm values of sensitizers with additional thiophene chromophore were broader in the region of 400-700 $\mathrm{nm}$ than those in the phenylene group, representing an advantageous spectral property for light harvesting and thus increasing the photocurrent response region.

3.2. Electrochemical Properties. In order to evaluate the feasibility of electron transfer from the excited dye molecule to the conduction band (CB) of $\mathrm{TiO}_{2}$ and the regeneration of oxidized dyes, the cyclic voltammetry $(\mathrm{CV})$ has been performed in $\mathrm{CH}_{2} \mathrm{Cl}_{2}$ solutions with $0.1 \mathrm{M}$ tetrabutylammonium hexafluorophosphate $\left(\mathrm{TBAPF}_{6}\right)$ as supporting electrolyte and a three-electrode configuration consisting of a glass carbon as working electrode, an auxiliary $\mathrm{Pt}$ wire electrode, and a saturated calomel electrode (SCE) reference electrode. All potentials reported are calibrated with $\mathrm{Fc} / \mathrm{Fc}^{+}$as an external reference. The relevant data are compiled in Table 1.

The $E_{0-0}$ values were estimated from the onset point of UV-vis spectra. As compared to BPI-P, both BPI-T and DPI-T have narrow $E_{0-0}$ values, a trend consistent with the wider absorption ranges illustrated in Figures 3 and 4 , indicating the additional linker with the thiophene moiety which reduces energy gap energies. The excited state potentials $\left(E_{\mathrm{ox}}{ }^{*}\right)$, which correspond to the lowest unoccupied molecular orbital (LUMO) levels, were estimated by 
TABLE 1: Photophysical and electrochemical data of three dyes.

\begin{tabular}{lccccccc}
\hline Dye & $\lambda_{\max }(\mathrm{nm})^{\mathrm{a}}$ & $\varepsilon \times 10^{-4}\left(\mathrm{M}^{-1} \cdot \mathrm{cm}^{-1}\right)^{\mathrm{a}}$ & $\lambda_{\max }(\mathrm{nm})^{\mathrm{b}}$ & $\mathrm{fwhm}_{(\mathrm{nm})^{\mathrm{c}}}$ & $E_{\text {ox }}{ }^{\text {onset }}(\mathrm{V})^{\mathrm{d}}$ & $E_{0,0}(\mathrm{eV})^{\mathrm{e}}$ & $E_{\text {ox }}{ }^{*}(\mathrm{~V})^{\mathrm{f}}$ \\
\hline BPI-P & 531 & 6.20 & 505 & $38(92)$ & 1.26 & $2.22(560 \mathrm{~nm})$ & -0.96 \\
BPI-T & 531 & 6.40 & 527 & $47(>175)$ & 1.19 & $2.11(588 \mathrm{~nm})$ & -0.92 \\
DPI-T & 532 & 8.02 & 528 & $49(170)$ & 1.20 & $2.11(589 \mathrm{~nm})$ & -0.91 \\
\hline
\end{tabular}

${ }^{a}$ Absorption maximum in $\mathrm{CHCl}_{3}$ solution. ${ }^{\mathrm{b}} \mathrm{Absorption}$ maximum on $\mathrm{TiO}_{2}$ was obtained through measuring the dyes adsorbed on $6 \mu \mathrm{m}$ TiO ${ }_{2}$ nanoparticle films. ${ }^{\mathrm{c}}$ Values in $\mathrm{CHCl}_{3}$ solutions (on $\mathrm{TiO}_{2}$ film). ${ }^{\mathrm{d}} E_{\text {ox }}{ }^{\text {onset }}$ was measured in $\mathrm{CH}_{2} \mathrm{Cl}_{2}$ with $0.1 \mathrm{M} \mathrm{TBAPF}_{6}$ as the electrolyte. ${ }^{\mathrm{e}} E_{0,0}$ was estimated from the onset point of the absorption spectra. ${ }^{\mathrm{f}} E_{\mathrm{ox}}{ }^{*}$ was estimated by subtracting $E_{0,0}$ from the $E_{\mathrm{ox}}{ }^{\text {onset }}$.

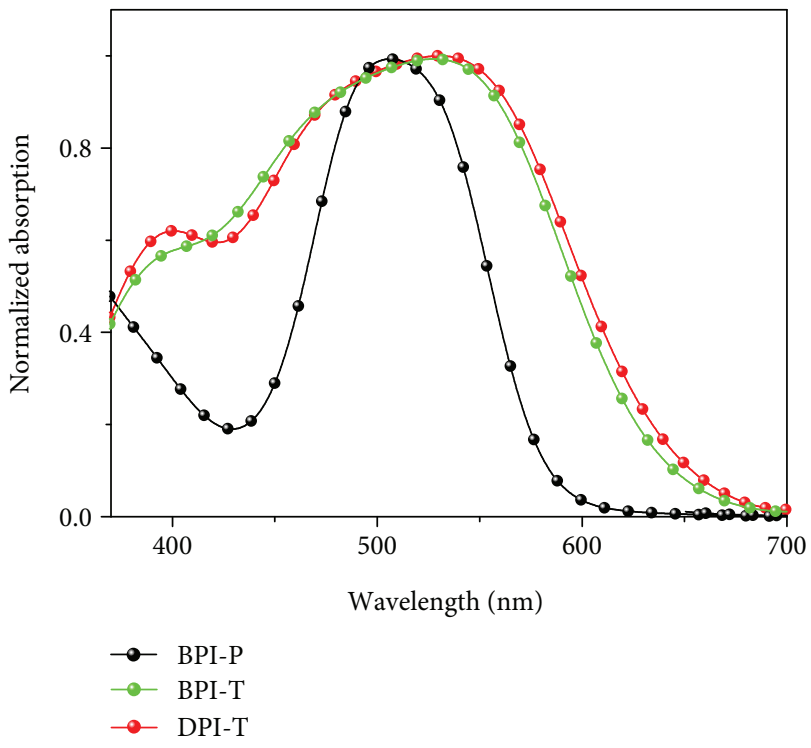

FIGURE 4: Normalized absorption spectra for BPI-P, BPI-T, and DPI-T immobilized on $\mathrm{TiO}_{2}$.

virtue of the following equation: $E_{\mathrm{ox}}{ }^{*}=E_{\mathrm{ox}}{ }^{\text {onset }}-E_{0,0}$, where $E_{\text {ox }}{ }^{\text {onset }}$ stands for the onset potential of oxidation of the ground state of a dye dissolved in $\mathrm{CH}_{2} \mathrm{Cl}_{2}$. As shown in Figure 5, all $E_{\mathrm{ox}}{ }^{*}$ values are more negative than the $\mathrm{CB}$ edge of $\mathrm{TiO}_{2}(-0.5 \mathrm{~V}$ versus $\mathrm{NHE})$, ensuring an efficient electron injection process from the excited state of the dyes into the $\mathrm{TiO}_{2}$ electrode. In contrast, the more positive oxidation potential of $E_{\text {ox }}$ onset corresponding to the highest occupied molecular orbital (HOMO) level of all photosensitizers compared with that of the $\mathrm{I}_{3}{ }^{-} / \mathrm{I}^{-}$redox couples $(0.42 \mathrm{~V}$ versus NHE) indicates that regeneration of the dyes is thermodynamically feasible. All dyes can be used as sensitizers for feasible electron transfer in DSSCs.

3.3. Computational Study. Density functional theory (DFT) calculations using the Gaussian 09 [38] software (B3LYP/ 6-31 G) were conducted in order to gain in-depth insight into the optimized geometrical configuration (Figure 6) and electron distribution of the frontier orbitals of the three molecules (Figure 7). Time-dependent density functional theory (TD-DFT) was then utilized at the same theoretical level to find vertical transitions (Table 2).

In the structure of BPI-P, the dihedral angle between the imidazole core and the adjacent phenyl ring is $41.9^{\circ}$, while in the case of BPI-T, the dihedral angle between imidazole and

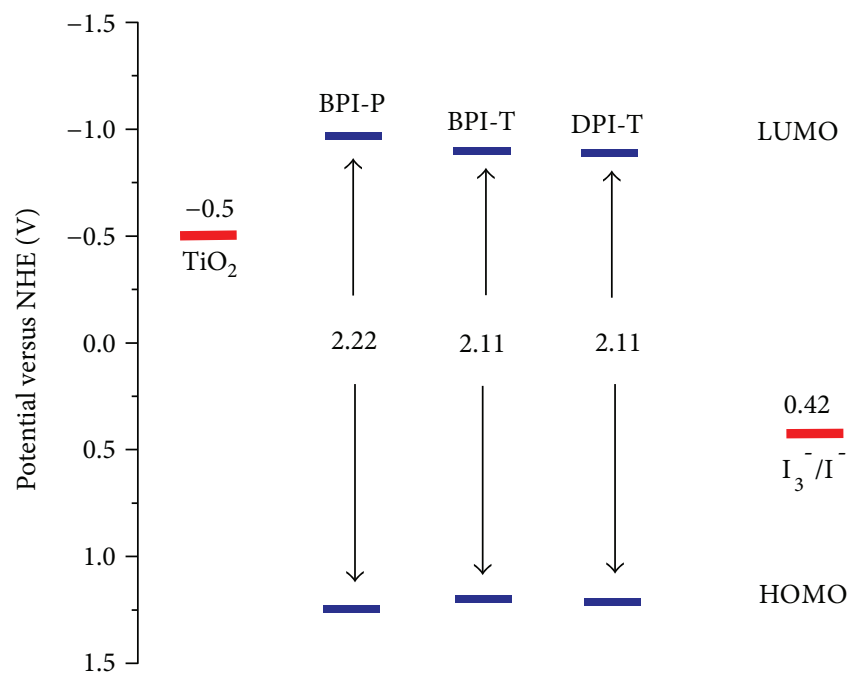

FIgure 5: Cyclic voltammogram of the dyes BPI-P, BPI-T, and DPI- $\mathrm{T}$ in $\mathrm{CH}_{2} \mathrm{Cl}_{2}$ solutions.

the neighboring 'thienyl ring is $19.0^{\circ}$. Encouragingly, when the BPI was replaced with DPI to construct DPI-T, the torsion angle calculated between the imidazole core and thiophene linker gets smaller $\left(9.7^{\circ}\right)$. Based on the calculated molecular geometry, a more distinctly molecular planar can be observed for DPI-T, which may naturally increase the effective conjugation and strengthen the charge transfer from the donor to the acceptor causing a broadening absorption spectrum compared to BPI-P and BPI-T.

From Table 2, the relative trend of UV-Vis absorption spectra based on the TD-DFT calculations is well consistent with our experimental values. The pathways for excitation and electron injection process can be learned by investigating and analyzing the computational results. For example, the low-energy band located in the range of 420 $675 \mathrm{~nm}$ can be assigned to HOMO/LUMO, HOMO-1/ LUMO, and HOMO-2/LUMO transitions. From Figure 7, the electron density of the HOMOs of all dyes is located primarily at the electron-rich BPI or DPI moiety and extended to the conjugated linker group, while the HOMO-1s and LUMOs are concentrated at electron withdrawing unit of cyanoacetic acid and its nearby Bodipy bridge. It is interesting to note that HOMO-2 of thienyl-containing dyes is localized on the whole molecular skeleton and phenylenecontaining dye is a donor part. The maximum oscillator strength $(f)$ for lower-energy transitions is higher for DPI-T (0.75) compared to that of BPI-T (0.58), respectively. The 

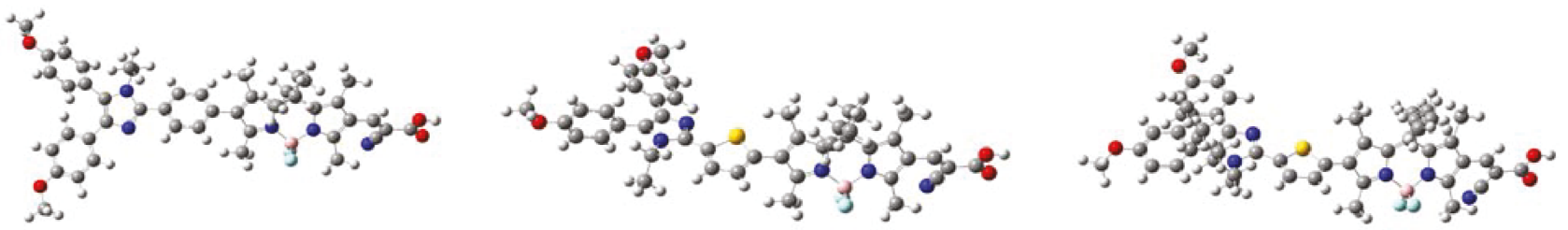

Figure 6: Optimized molecular structures of molecules BPI-P (left), BPI-T (middle), and DPI-T (right).

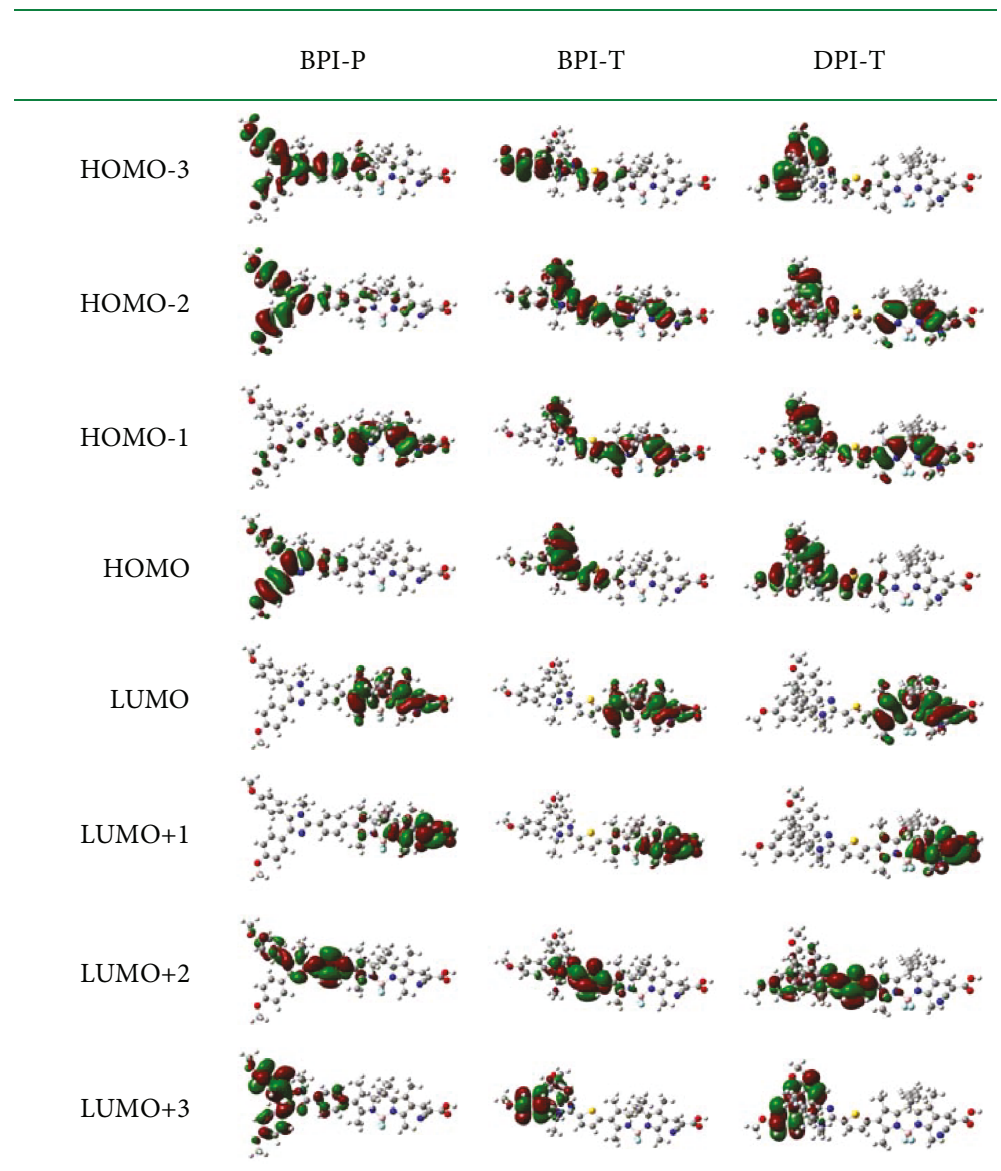

FIGURE 7: Frontier molecular orbitals of the dyes calculated with DFT on a B3LYP/6-31G (d) level.

results were consistent with the molar absorption coefficient of the dyes in solution. As shown in Table 2, the excited electrons could be successfully transferred from the HOMO or HOMO-1 or HOMO-2 to LUMO upon photoexcitation, facilitating the charge separation in the molecular and ensuring subsequent electron injection into the conduction band of the $\mathrm{TiO}_{2}$ semiconductor.

Overall, the results of DFT and TD-DFT calculations give a better understanding of electronic structures and optical properties and the nature of transition of synthesized molecules. Previous relevant studies have reported that a disturbance to charge delivery, through either a distortion of the molecular geometry or intramolecular aggregation, may reduce charge migration rate [39]. Better coplanar geometry and hydrophobic long chains
$\left(n-\mathrm{C}_{8} \mathrm{H}_{17}\right)$ in DPI-T might be favorable to reduce intermolecular aggregation and dark current.

3.4. Photovoltaic Performance of DSSCs Based on the Bodipy Dyes. The typical photocurrent-voltage $(J-V)$ curves of the devices fabricated with BPI-P, BPI-T, and DPI-T as sensitizers under the illumination of AM $1.5 \mathrm{G}\left(100 \mathrm{~mW} \cdot \mathrm{cm}^{-2}\right)$ are shown in Figure 8. The photovoltaic conversion efficiency $(\eta)$ of the DSSCs is calculated from short-circuit current density $\left(J_{\mathrm{sc}}\right)$, open-circuit voltage $\left(V_{\mathrm{oc}}\right)$, fill factor (ff), and intensity of the incident light $(P)$ according to the following equation: $\eta(\%)=\left(J_{\mathrm{sc}} \times V_{\mathrm{oc}} \times \mathrm{ff} / P\right) \times 100$. The detailed photovoltaic parameters are summarized in Table 3.

The overall $\eta$ for phenylene-conjugated derivative (BPI-P) and thiophene-linked analogue (BPI-T) are $0.18 \%$ 
TABLE 2: Calculated excitation energy characteristics of BPI-T and DPI-T.

\begin{tabular}{lcccc}
\hline Molecule & $\begin{array}{c}\text { Wavelength } \\
(\mathrm{nm})\end{array}$ & $f^{\mathrm{a}}$ & $\begin{array}{c}\text { Energy level } \\
(\mathrm{eV})\end{array}$ & Composition (\%) \\
\hline \multirow{4}{*}{ BPI-T } & 690 & 0.04 & 1.80 & $\mathrm{H} \rightarrow \mathrm{L}(70 \%)$ \\
& 481 & 0.35 & 2.58 & $\mathrm{H}-1 \rightarrow \mathrm{L}(64 \%)$ \\
& 444 & 0.58 & 2.79 & $\mathrm{H}-2 \rightarrow \mathrm{L}(57 \%)$ \\
& 377 & 0.13 & 3.28 & $\mathrm{H}-5 \rightarrow \mathrm{L}(61 \%)$ \\
& 354 & 0.24 & 3.50 & $\mathrm{H} \rightarrow \mathrm{L}+2(64 \%)$ \\
& 302 & 0.12 & 4.11 & $\mathrm{H}-3 \rightarrow \mathrm{L}+1(59 \%)$ \\
\hline \multirow{3}{*}{ DPI-T } & 735 & 0.06 & 1.69 & $\mathrm{H} \rightarrow \mathrm{L}(70 \%)$ \\
& 481 & 0.34 & 2.58 & $\mathrm{H}-1 \rightarrow \mathrm{L}(64 \%)$ \\
& 454 & 0.75 & 2.73 & $\mathrm{H}-2 \rightarrow \mathrm{L}(67 \%)$ \\
& 388 & 0.45 & 3.19 & $\mathrm{H} \rightarrow \mathrm{L}+2(45 \%)$ \\
& 301 & 0.13 & 4.11 & $\mathrm{H}-4 \rightarrow \mathrm{L}+1(52 \%)$ \\
\hline
\end{tabular}

${ }^{\mathrm{a}}$ The oscillator strength of a transition. ${ }^{\mathrm{b}}$ The composition means contribution of each transition for excitation energies. ${ }^{c} \mathrm{H} \rightarrow \mathrm{HOMO}$; $\mathrm{L} \rightarrow \mathrm{LUMO}$.

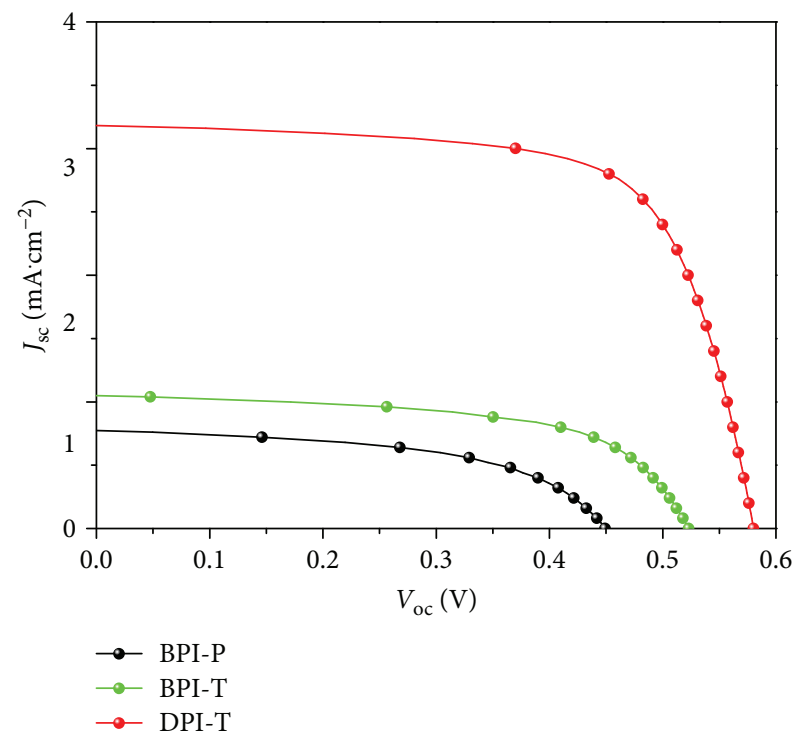

FIGURE 8: The photocurrent density-voltage curve for DSSCs based on BPI-P, BPI-T, and DPI-T under AM 1.5 full simulated sunlight irradiation.

$\left(J_{\text {sc }}=0.76 \mathrm{~mA} / \mathrm{cm}^{2}, V_{\text {oc }}=0.45 \mathrm{~V}\right.$, and $\left.\mathrm{ff}=0.54\right)$ and $0.32 \%$ $\left(J_{\mathrm{sc}}=1.04 \mathrm{~mA} / \mathrm{cm}^{2}, V_{\mathrm{oc}}=0.52 \mathrm{~V}\right.$, and $\left.\mathrm{ff}=0.60\right)$, respectively. Under the same conditions, the solar cell based on reference dye DPI-T generated an efficiency of $1.28 \%$, with a $J_{\mathrm{sc}}$ of $3.18 \mathrm{~mA} / \mathrm{cm}^{2}$, a $V_{\text {oc }}$ of $0.58 \mathrm{~V}$, and an ff of 0.69 . Despite their relatively low overall conversion efficiencies, the dyes show amusing structural dependence in their DSSC performance. Both $V_{\mathrm{oc}}$ and $J_{\mathrm{sc}}$ increase with the thiophene units. The difference in performance between the BPI-P and BPI-T probably stems from the difference in the coplanarity of the aromatic segment that links the donor and $\pi$ bridge unit. According to the DFT study, the phenylene derivative possesses a more
TABLE 3: Photovoltaic performance of DSSCs based on the Bodipy series of dyes.

\begin{tabular}{lcccc}
\hline Dye & $J_{\text {sc }}\left(\mathrm{mA} / \mathrm{cm}^{2}\right)$ & $V_{\text {oc }}(\mathrm{V})$ & $\mathrm{ff}$ & $\eta(\%)$ \\
\hline BPI-P & 0.76 & 0.45 & 0.54 & 0.18 \\
BPI-T & 1.04 & 0.52 & 0.60 & 0.32 \\
DPI-T & 3.18 & 0.58 & 0.69 & 1.28 \\
\hline
\end{tabular}

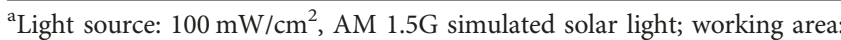
$0.25 \mathrm{~cm}^{2}$; thickness: $14.5 \mathrm{um}$; dye bath: $\mathrm{CHCl}_{3}$ solution $(0.3 \mathrm{mM})$; and electrolyte: $0.05 \mathrm{M} \mathrm{I}_{2}+0.1 \mathrm{M} \mathrm{LiI}+0.6 \mathrm{M} \mathrm{DMPImI}+0.5 \mathrm{M}$ TBP in $\mathrm{CH}_{3} \mathrm{CN}$ solution.

twisted nonplanar geometry, which leads to poor orbital overlap. As a result, the benzene ring cannot be of benefit to the conjugated system and unflavored the electron injection. It is confirmed that the introduction of phenylene lowered the extinction coefficient not only in the ultraviolet regions but also in the visible regions, compared with the thiophene-linked dye (Figure 3). Hence, the photocurrent dropped due to the inefficient light harvest. The thiophenelinked analogues possess a high planar configuration, which can lead to an increased intermolecular $\pi-\pi^{*}$ interaction. Compared to the devices using BPI-T and BPI-P with the BPI as the electron donor, the device based on DPI-T has dramatically improved $\eta$ of $1.28 \%$. Thus, the order of photovoltaic performance is DPI-T $>$ BPI-T $>$ BPI-P, consistent with their light-harvesting ability.

It is found that DPI-T shows a higher photocurrent than BPI-T due to the excellent conjugation system with relatively better electron-donating ability and smaller steric hindrance, which produces a broader absorption spectrum and a higher extinction coefficient. Previous reports have revealed that the long hydrophobic chain might effectively suppress the electron recombination and reduce the interaction between the dye molecules [40, 41], and in this study, DPI-T with octyl chain in the 1-site of the imidazolyl ring exhibited higher $V_{\text {oc }}$ than the sensitizers with ethyl chain in the same substitution site.

\section{Conclusions}

In summary, two new 4,5-bis(4-methoxyphenyl)-1H-imidazole (BPI) organic dyes BPI-P and BPI-T containing the same Bodipy-conjugated bridges and different additional linkers (phenylene/thiophene) were designed and synthesized. Their optical DFT calculations and photovoltaic properties were systematically investigated because of their promising potential as efficient photosensitizers in DSSCs. The BPI-P- and BPI-T-based cell generated the overall $\eta$ of $0.18 \%$ and $0.32 \%$, respectively, whereas the reference dye DPI-T-based cell gave the efficiency of $1.28 \%$. Dye DPI-T was found to be more efficient than both BPI-P and BPI-T and is attributed to its relatively outstanding light-harvesting efficiency as a result of smaller steric hindrance between the thiophene and DPI unit and better extension of $\pi$-conjugated system with four rings on the donor. 


\section{Conflicts of Interest}

The authors declare that there is no conflict of interests regarding the publication of this paper.

\section{Acknowledgments}

This work was supported by grants from the Natural Science Foundation of China (nos. 21406189 and 41505127).

\section{References}

[1] X. L. Zhang and M. Mao, "Brown haze types due to aerosol pollution at Hefei in the summer and fall," Chemosphere, vol. 119, pp. 1153-1162, 2015.

[2] X. L. Zhang, M. Mao, M. J. Berg, and W. B. Sun, "Insight into winter time aerosol characteristics over Beijing," Journal of Atmospheric and Solar-Terrestrial Physics, vol. 121, pp. 6371, 2014.

[3] X. L. Zhang, M. Mao, Y. Yin, and B. Wang, "Absorption enhancement of aged black carbon aerosols affected by their microphysics: a numerical investigation," Journal of Quantitative Spectroscopy \& Radiative Transfer, vol. 202, pp. 90-97, 2017.

[4] X. L. Zhang, M. Mao, Y. Yin, and B. Wang, "Numerical investigation on absorption enhancement of black carbon aerosols partially coated with non-absorbing organics," Journal of Geophysical Research: Atmospheres, vol. 123, 2018.

[5] B. O’Regan and M. Grätzel, "A low-cost, high-efficiency solar cell based on dye-sensitized colloidal $\mathrm{TiO}_{2}$ films," Nature, vol. 353, no. 6346, pp. 737-740, 1991.

[6] A. Hagfeldt, G. Boschloo, L. Sun, L. Kloo, and H. Pettersson, "Dye-sensitized solar cells," Chemical Reviews, vol. 110, no. 11, pp. 6595-6663, 2010.

[7] Z. Ning, Y. Fu, and H. Tian, "Improvement of dye-sensitized solar cells: what we know and what we need to know," Energy \& Environmental Science, vol. 3, no. 9, pp. 1170-1181, 2010.

[8] H. S. Jung and J. K. Lee, "Dye sensitized solar cells for economically viable photovoltaic systems," Journal of Physical Chemistry Letters, vol. 4, no. 10, pp. 1682-1693, 2013.

[9] M. Urbani, M. Grätzel, M. K. Nazeeruddin, and T. Torres, "Meso-substituted porphyrins for dye-sensitized solar cells," Chemical Reviews, vol. 114, no. 24, pp. 12330-12396, 2014.

[10] M. Grätzel, "Photoelectrochemical cells," Nature, vol. 414, no. 6861, pp. 338-344, 2001.

[11] A. Listorti, B. O’Regan, and J. R. Durrant, "Electron transfer dynamics in dye-sensitized solar cells," Chemistry of Materials, vol. 23, no. 15, pp. 3381-3399, 2011.

[12] J. N. Clifford, E. Martínez-Ferrero, A. Viterisi, and E. Palomares, "Sensitizer molecular structure-device efficiency relationship in dye sensitized solar cells," Chemical Society Reviews, vol. 40, no. 3, pp. 1635-1646, 2011.

[13] M. Grätzel, R. A. J. Janssen, D. B. Mitzi, and E. H. Sargent, "Materials interface engineering for solution-processed photovoltaics," Nature, vol. 488, no. 7411, pp. 304-312, 2012.

[14] D. Joly, L. Pellejà, S. Narbey et al., "Metal-free organic sensitizers with narrow absorption in the visible for solar cells exceeding 10\% efficiency," Energy \& Environmental Science, vol. 8, no. 7, pp. 2010-2018, 2015.

[15] Y. Wu and $W$. Zhu, "Organic sensitizers from $D-\pi-A$ to $\mathrm{D}-\mathrm{A}-\pi-\mathrm{A}$ : effect of the internal electron-withdrawing units on molecular absorption, energy levels and photovoltaic performances," Chemical Society Reviews, vol. 42, no. 5, pp. 2039-2058, 2013.

[16] R. Grisorio, L. De Marco, R. Agosta et al., "Enhancing dyesensitized solar cell performances by molecular engineering: highly efficient $\pi$-extended organic sensitizers," ChemSusChem, vol. 7, no. 9, pp. 2659-2669, 2014.

[17] F. Zhang, K. J. Jiang, J. H. Huang et al., “A novel compact DPP dye with enhanced light harvesting and charge transfer properties for highly efficient DSCs," Journal of Materials Chemistry A, vol. 1, no. 15, pp. 4858-4863, 2013.

[18] N. Nagarajan, G. Vanitha, D. A. Ananth, A. Rameshkumar, T. Sivasudha, and R. Renganathan, "Bioimaging, antibacterial and antifungal properties of imidazole-pyridine fluorophores: synthesis, characterization and solvatochromism," Journal of Photochemistry and Photobiology B: Biology, vol. 127, pp. 212-222, 2013.

[19] F. Bellina, S. Cauteruccio, S. Montib, and R. Rossia, "Novel imidazole-based combretastatin A-4 analogues: evaluation of their in vitro antitumor activity and molecular modeling study of their binding to the colchicine site of tubulin," Bioorganic \& Medicinal Chemistry Letters, vol. 16, no. 22, pp. 5757-5762, 2006.

[20] A. Melaiye, Z. Sun, K. Hindi et al., "Silver(I)-imidazole cyclophane gem-diol complexes encapsulated by electrospun tecophilic nanofibers: formation of nanosilver particles and antimicrobial activity," Journal of the American Chemical Society, vol. 127, no. 7, pp. 2285-2291, 2005.

[21] B. F. Abdel-Wahab, G. E. A. Awad, and F. A. Badria, "Synthesis, antimicrobial, antioxidant, anti-hemolytic and cytotoxic evaluation of new imidazole-based heterocycles," European Journal of Medicinal Chemistry, vol. 46, no. 5, pp. 15051511, 2011.

[22] Y. Zhang, S. L. Lai, Q. X. Tong et al., "High efficiency nondoped deep-blue organic light emitting devices based on imidazole- $\pi$-triphenylamine derivatives," Chemistry of Materials, vol. 24, no. 1, pp. 61-70, 2011.

[23] H. Huang, X. Yang, B. Pan et al., "Benzimidazole-carbazolebased bipolar hosts for high efficiency blue and white electrophosphorescence applications," Journal of Materials Chemistry, vol. 22, no. 26, pp. 13223-13230, 2012.

[24] X. Yang, S. Zheng, R. Bottger et al., "Efficient fluorescent deepblue and hybrid white emitting devices based on carbazole/ benzimidazole compound," Journal of Physical Chemistry C, vol. 115, no. 29, pp. 14347-14352, 2011.

[25] S. Park, J. E. Kwon, S. H. Kim et al., "A white-light-emitting molecule: frustrated energy transfer between constituent emitting centers," Journal of the American Chemical Society, vol. 131, no. 39, pp. 14043-14049, 2009.

[26] N. Nagarajan, A. Prakash, G. Velmurugan et al., "Synthesis, characterization and electroluminescence behaviour of $\pi$-conjugated imidazole-isoquinoline derivatives," Dyes and Pigments, vol. 102, pp. 180-188, 2014.

[27] M. Velusamy, Y. Hsu, J. T. Lin, C. W. Chang, and C. P. Hsu, "1-Alkyl-1H-imidazole-based dipolar organic compounds for dye-sensitized solar cells," Chemistry - An Asian Journal, vol. 5, no. 1, pp. 87-96, 2010.

[28] N. Nagarajan, G. Velmurugan, P. Venuvanalingam, and R. Renganathan, "Tunable single and dual emission behavior of imidazole fluorophores based on D- $\pi$-A architecture," Journal of Photochemistry and Photobiology A: Chemistry, vol. 284, pp. 36-48, 2014. 
[29] R. K. Aulakh, S. Sandhu, S. Kumar, A. Mahajan, R. K. Bedi, and S. Kumar, "Designing and synthesis of imidazole based hole transporting material for solid state dye sensitized solar cells," Synthetic Metals, vol. 205, pp. 92-97, 2015.

[30] Z. Wan, L. Zhou, C. Jia, X. Chen, Z. Li, and X. Yao, "Comparative study on photovoltaic properties of imidazole-based dyes containing varying electron acceptors in dye-sensitized solar cells," Synthetic Metals, vol. 196, pp. 193-198, 2014.

[31] D. Karthik, V. Kumar, K. J. Thomas, C. T. Li, and K. C. Ho, "Synthesis and characterization of thieno[3,4- d ]imidazolebased organic sensitizers for photoelectrochemical cells," Dyes and Pigments, vol. 129, pp. 60-70, 2016.

[32] A. Loudet and K. Burgess, "BODIPY dyes and their derivatives: syntheses and spectroscopic properties," Chemical Reviews, vol. 107, no. 11, pp. 4891-4932, 2007.

[33] S. Kolemen, O. A. Bozdemir, Y. Cakmak et al., "Optimization of distyryl-Bodipy chromophores for efficient panchromatic sensitization in dye sensitized solar cells," Chemical Science, vol. 2, no. 5, pp. 949-954, 2011.

[34] M. Mao, X. L. Zhang, X. Q. Fang et al., "Highly efficient lightharvesting boradiazaindacene sensitizers for dye-sensitized solar cells featuring phenothiazine donor antenna," Journal of Power Source, vol. 268, pp. 965-976, 2014.

[35] C. Qin, A. Mirloup, N. Leclerc et al., "Molecular engineering of new thienyl-Bodipy dyes for highly efficient panchromatic sensitized solar cells," Advanced Energy Materials, vol. 4, no. 11, article 1400085, 2014.

[36] M. Mao and Q. H. Song, "The structure-property relationships of D- $\pi$-A BODIPY dyes for dye-sensitized solar cells," The Chemical Record, vol. 16, no. 2, pp. 719-733, 2016.

[37] M. Mao, J. B. Wang, Z. F. Xiao, S. Y. Dai, and Q. H. Song, "New 2,6-modified BODIPY sensitizers for dye-sensitized solar cells," Dyes and Pigments, vol. 94, no. 2, pp. 224-232, 2012.

[38] M. J. Frisch, G. W. Trucks, H. B. Schlegel et al., Gaussian 09, Revision E.01, Gaussian, Inc, Wallingford, CT, USA, 2009.

[39] R. Y. Huang, Y. H. Chiu, Y. H. Chang et al., "Influence of a $D-\pi$-A system through a linked unit of double and triple bonds in a triarylene bridge for dye-sensitised solar cells," New Journal of Chemistry, vol. 41, no. 16, pp. 8016-8025, 2017.

[40] Z. Wan, C. Jia, Y. Wang, and X. Yao, "Dithiafulvenyl-triphenylamine organic dyes with alkyl chains for efficient coadsorbent-free dye-sensitized solar cells," RSC Advances, vol. 5, no. 63, pp. 50813-50820, 2015.

[41] B. Nagarajan, S. Kushwaha, R. Elumalai, and S. Mandal, "Novel ethynyl-pyrene substituted phenothiazine based metal free organic dyes in DSSC with $12 \%$ conversion efficiency," Journal of Materials Chemistry A, vol. 5, no. 21, pp. 1028910300, 2017. 

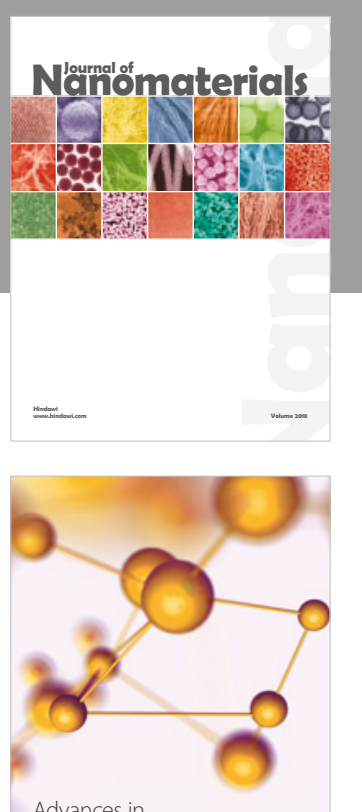

Physical Chemistry
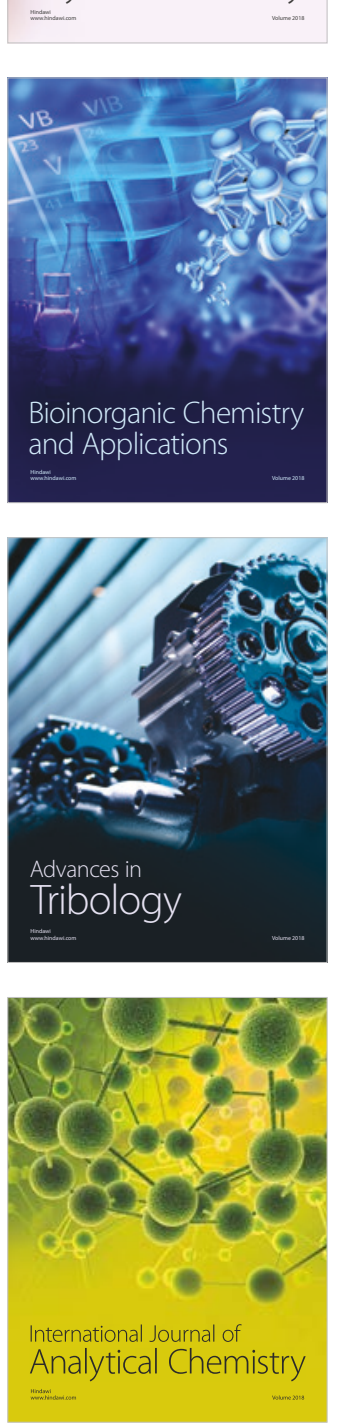

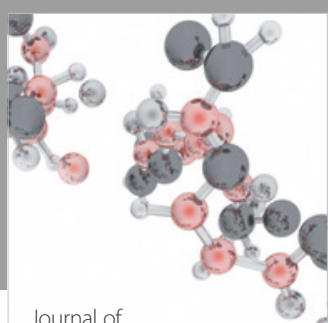

Analytical Methods

in Chemistry

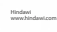

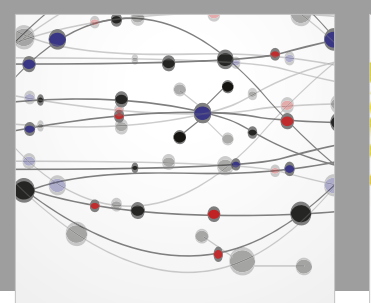

The Scientific World Journal

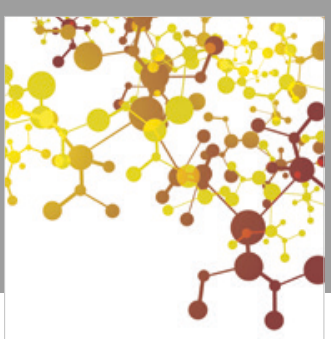

Journal of

Applied Chemistry
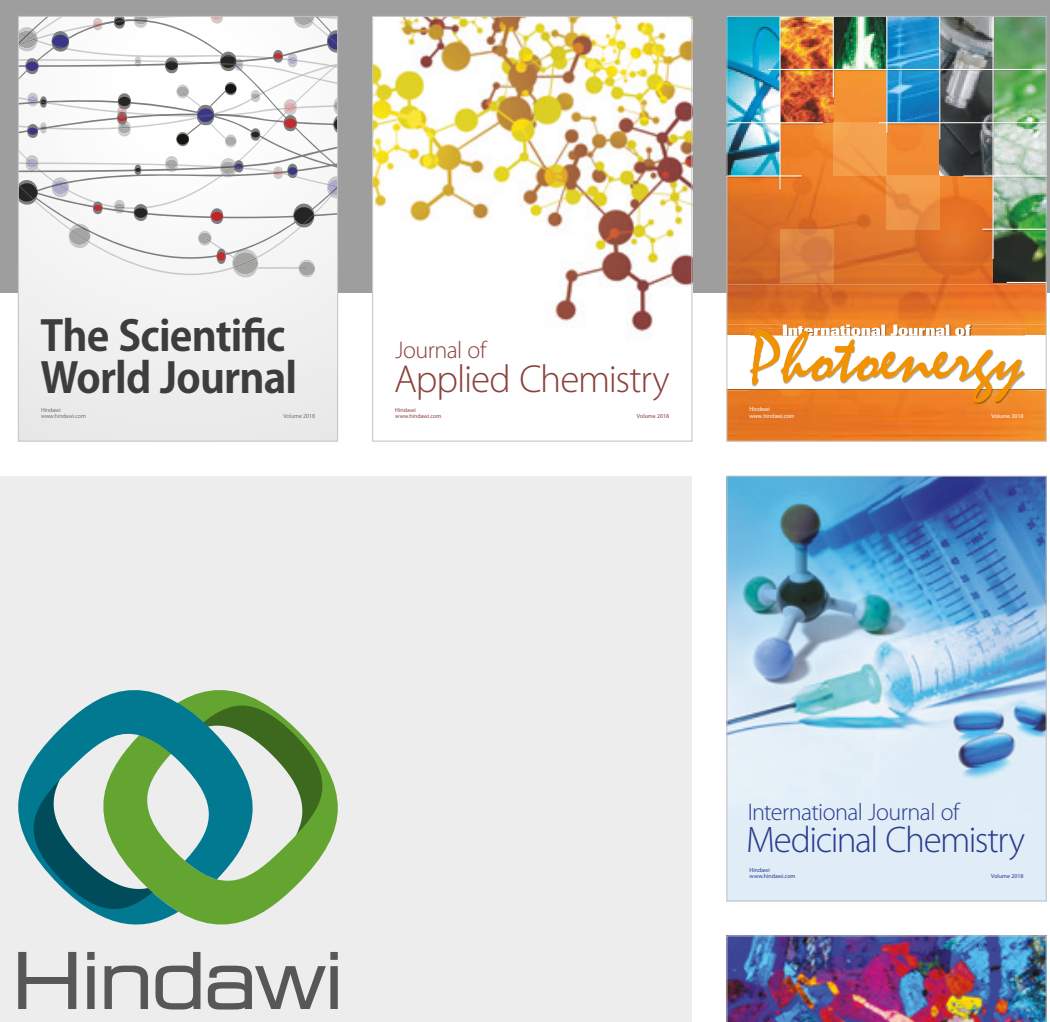

Submit your manuscripts at

www.hindawi.com
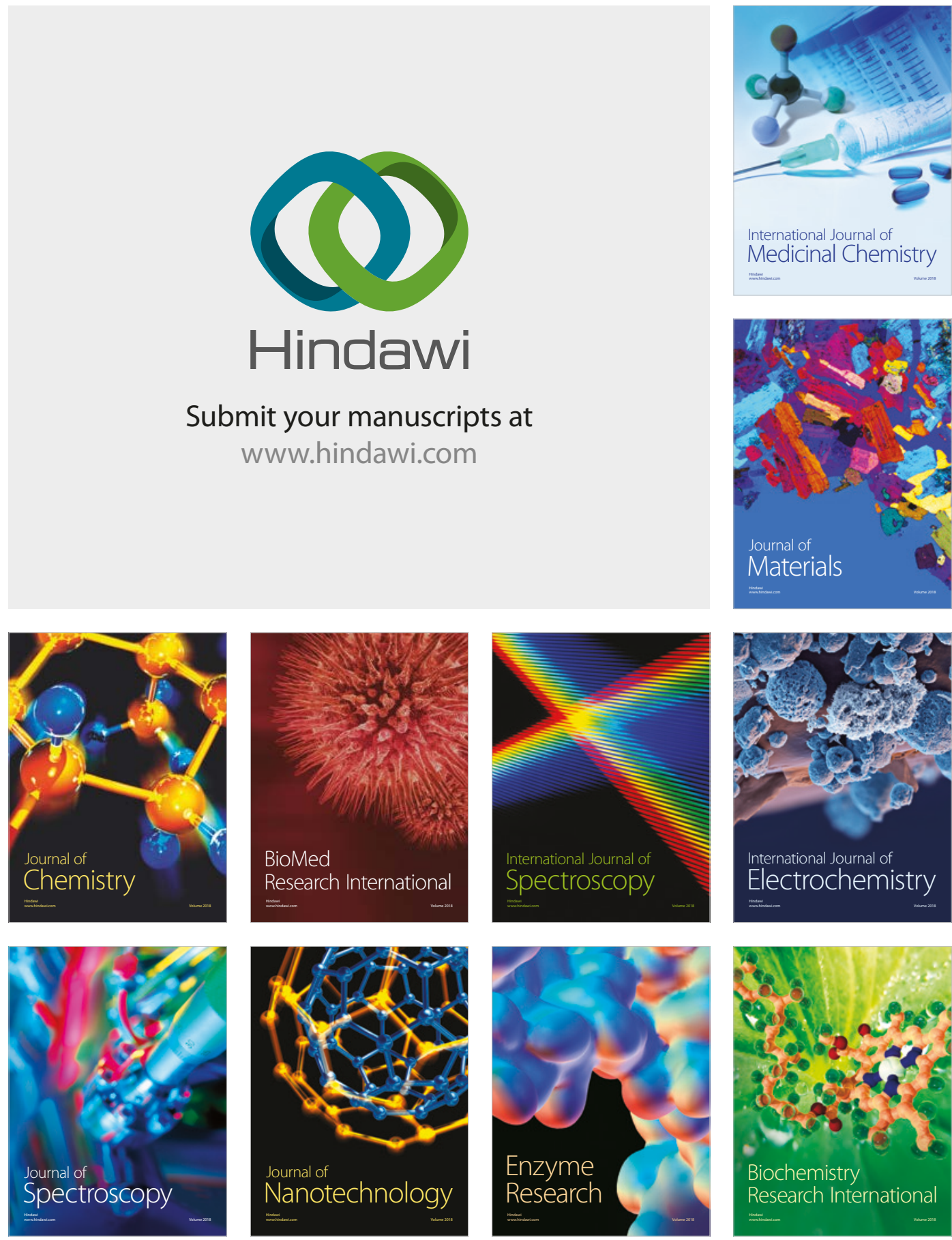
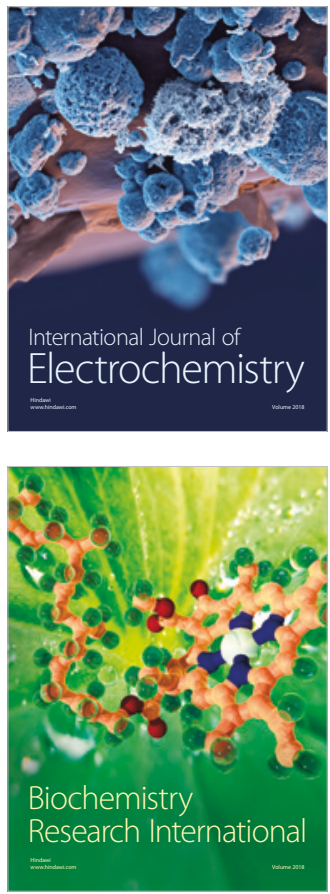